\title{
IUSS SUITMA 6 International Symposium 2011
}

\author{
Nicholas Dickinson • Jean-Louis Morel • \\ Richard K. Shaw • Gerd Wessolek
}

Received: 15 January 2013 / Accepted: 23 January 2013 / Published online: 8 February 2013

(C) Springer-Verlag Berlin Heidelberg 2013

Soils in urban, industrial, traffic, mining and military areas (SUITMA) is a working group of the International Union of Soil Sciences created in 1998 to increase and promote soil science in strongly anthropized areas (Morel and Heinrich 2008). Originally dedicated to basic soil science aimed at the description, analysis, classification, and mapping of soils developed in humantransformed environments, i.e., the SUITMAs, which exhibit contrasting features in comparison with natural soils, the SUITMA group interest has shifted towards the study of soil functions, their status and restoration, and their role in the functioning and evolution of urban ecosystems.

Every 2 years, the SUITMA group organizes a conference (i.e., Essen, Nancy, Cairo, Nanjing, New York City, Marrakech) which gathers 100-150 scientists and professionals whose activities are centered in urban and peri-urban environments. The 2011 conference (SUITMA 6) was held

\author{
N. Dickinson \\ Department of Ecology, Lincoln University, \\ PO Box 84, Lincoln, Canterbury 7647, New Zealand \\ J.-L. Morel $(\bowtie)$ \\ University of Lorraine-INRA, \\ 2, avenue de la Forêt de Haye, TSA 40602 , \\ 54618 Vandoeuvre-lès-Nancy, France \\ e-mail: Jean-Louis.Morel@univ-lorraine.fr \\ R. K. Shaw \\ USDA-NRCS, 220 Davidson Avenue, \\ 4th Floor, Somerset, NJ 08873, USA \\ G. Wessolek \\ Faculty VI, Institute of Ecology, Technical University \\ Berlin, Salzufer 12, 10587 Berlin, Germany
}

in Marrakech, Morocco. It was co-organized by the Faculté des Sciences et Techniques of Marrakech and the GISFI (http://www.gisfi.fr). One hundred participants attended the conference and a total of 45 communications and 48 posters were presented in four sessions: session 1: SUITMA properties and diversity, contamination, and remediation; session 2: role of SUITMAs in global change and water quality; session 3: biodiversity in SUITMAs; and session 4: SUITMAs as buffer for human health and social stability. Eleven peer-reviewed papers are being published in this special issue of the Journal of Soils and Sediments, which focus on the properties, processes, evolution, and management of soils in urban and human-altered environments. Targets of study include soils with technic materials (Abakumov et al. 2013; El Khalil et al. 2013; Houben et al. 2013; Huot et al. 2013; Nehls et al. 2013; Schonsky et al. 2013), those with elevated metal contents (Aboudrar et al. 2013; Jean-Soro et al. 2013), soils in storm water infiltration basins (Coulon et al. 2013; El-Mufleh et al. 2013), and soils with landmines (Preetz et al. 2013).

The conference was completed with a 2-day field trip in Marrakech and its vicinity to study the impacts of mining activities on soils, the consumption of agricultural soils by urbanization (e.g., the Palmeraie of Marrakech), the management of water in arid zones, and the creation of urban parks.

During the meeting, Torun, Poland, was selected for the next conference (SUITMA 7, September 16-22, 2013; http://www.suitma7.umk.pl). SUITMA will also be present in 2014 at the 20th World Congress of Soil Science in Jeju, South Korea, with a symposium entitled "Urban soils-properties, functions, and evolution." We look forward to welcoming new members and old friends at both events. 


\section{References}

Abakumov EV, Cajthaml T, Brus J, Frouz J (2013) Humus accumulation, humification, and humic acid composition in soils of two post-mining chronosequences after coal mining. J Soils Sediments (this issue)

Aboudrar W, Schwartz C, Morel J-L, Boularbah A (2013) Effect of nickel-resistant rhizosphere bacteria on the uptake of nickel by the hyperaccumulator Noccaea caerulescens under controlled conditions. J Soils Sediments (this issue)

Coulon A, El-Mufleh A, Cannavo P, Vidal-Beaudet L, Béchet B, Charpentier S (2013) Specific stability of organic matter in a stormwater infiltration basin. J Soils Sediments (this issue)

El Khalil H, Schwartz C, El Hamiani O, Kubiniok J, Morel J-L, Boularbah A (2013) Distribution of major elements and trace metals as indicators of technosolisation of urban and suburban soils. J Soils Sediments (this issue)

El-Mufleh A, Béchet B, Grasset L, Rodier C, Gaudin A, Ruban V (2013) Distribution of PAH residues in humic and mineral fractions of sediments from stormwater infiltration basins. J Soils Sediments (this issue)

Houben D, Couder E, Sonnet P (2013) Leachability of cadmium, lead, and zinc in a long-term spontaneously revegetated slag heap: implications for phytostabilization. J Soils Sediments (this issue)

Huot H, Simonnot M-O, Marion P, Yvon J, De Donato D, Morel J-L (2013) Characteristics and potential pedogenetic processes of a
Technosol developing on iron industry deposits. J Soils Sediments (this issue)

Jean-Soro L, Oleron-Hamdous A, Béchet B, Legret M (2013) Evaluation of platinum distribution between different soil components. J Soils Sediments (this issue)

Morel J-L, Heinrich AB (2008) SUITMA — Soils in urban, industrial, traffic, mining and military areas. An interdisciplinary working group of the 'International Union of Soil Science' (IUSS) dedicated to soils strongly modified by human activities. J Soils Sediments 8(4):206-207

Nehls T, Rokia S, Mekiffer B, Schwartz C, Wessolek G (2013) Contribution of bricks to urban soil properties. J Soils Sediments (this issue)

Preetz H, Rolf C, Igel J (2013) Soil influence of landmine detection-insights from a field study in Mozambique. J Soils Sediments (this issue)

Schonsky H, Peters A, Lang F, Abel S, Mekiffer B, Wessolek G (2013) Sulfate transport and releases in technogenic soil substrate: experiments and numerical modeling. J Soils Sediments (this issue)

Guest Editors of this special issue are: Nicholas Dickinson, Jean-Louis Morel, Richard Shaw, and Gerd Wessolek. 